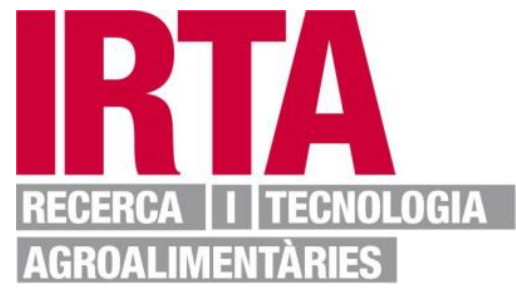

This document is a postprint version of an article published in Environmental Research (C) Elsevier after peer review. To access the final edited and published work see https://doi.org/10.1016/i.envres.2017.11.028 


\title{
Occurrence of Cyclic Imines in European commercial seafood and consumers risk assessment
}

Maria Rambla-Alegre ${ }^{1}$, Christopher O. Miles ${ }^{2,3}$, Pablo de la Iglesia ${ }^{1}$, Margarita Fernandez-Tejedor ${ }^{1}$, Silke Jacobs ${ }^{4,5}$, Isabelle Sioen ${ }^{6}$, Wim Verbeke ${ }^{4}$, Ingunn A. Samdal ${ }^{3}$, Morten Sandvik ${ }^{3}$, Vera Barbosa ${ }^{7}$, Alice Tediosi ${ }^{8}$, Eneko Madorran ${ }^{9}$, Kit Granby ${ }^{10}$, Michiel Kotterman ${ }^{11}$, Tanja Calis ${ }^{12}$, Jorge Diogene ${ }^{1}$

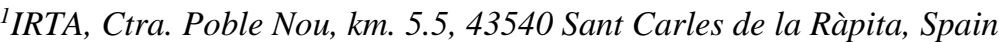

${ }^{2}$ Norwegian Veterinary Institute, P.O. Box 750 Sentrum, N-0106 Oslo, Norway

${ }^{3}$ National Research Council Canada, 1411 Oxford St., Halifax, Nova Scotia, B3H $3 Z 1$

${ }^{4}$ Department of Agricultural Economics, Ghent University, Block A, Coupure Links 653, 9000 Gent, Belgium

${ }_{5}^{5}$ Department of Public Health, Ghent University, UZ 4K3, De Pintelaan 185, 9000 Ghent, Belgium

${ }^{6}$ Department of Food Safety and Food Quality, Ghent University, Block B, Coupure Links 653, 9000 Ghent, Belgium

${ }^{7}$ Portuguese Institute for the sea and atmosphere, I.P. (IPMA), Avenida de Brasília, 1449-006 Lisbon, Portugal ${ }^{8}$ Aeiforia Srl, 29027 Gariga di Podenzano (PC), Italy

${ }^{9}$ University of Maribor, Faculty of Medicine, Institute of Anatomy, Taborska ulica 8, 2000 Maribor, Slovenia

${ }^{10}$ Technical University of Denmark, National Food Institute, Moerkhoej Bygade 19, 2860 Soeborg, Denmark

${ }^{11}$ IMARES Wageningen-UR, Haringkade 1, 1976 CP Ijmuiden, The Netherlands

${ }^{12}$ AQUATT, Olympic House, Pleasants Street, Dublin 8, Ireland

e-mail: maria.rambla@irta.cat

\begin{abstract}
Cyclic imines constitute a quite recently discovered group of marine biotoxins that act on neural receptors and that bioaccumulate in seafood. They are grouped together due to the imino group functioning as their common pharmacore, responsible for acute neurotoxicity in mice. Cyclic imines (CIs) have not been linked yet to human poisoning and are not regulated in Europe, although the European Food Safety Authority (EFSA) requires more data to perform conclusive risk assessment for consumers. Several commercial samples of bivalves including raw and processed samples from eight different countries (Italy, Portugal, Slovenia, Spain, Ireland, Norway, The Netherlands and Denmark) were obtained over 2 years. Emerging cyclic imine concentrations in all the samples were analysed on a LC-3200QTRAP and LC-HRMS QExactive mass spectrometer. In shellfish, two CIs, pinnatoxin G (PnTX-G) and 13-desmethylspirolide C (SPX-1) were found at low concentrations (0.1 to $12 \mu \mathrm{g} / \mathrm{kg}$ PnTX-G and 26 to $66 \mu \mathrm{g} / \mathrm{kg}$ SPX-1), while gymnodimines and pteriatoxins were not detected in commercial samples (raw and processed samples). In summary, SPX-1 (n: 47) and PnTX-G (n: 96) were detected in $9.4 \%$ and $4.2 \%$ of the samples, respectively, at concentrations higher than the limit of quantification (LOQ), and in $7.3 \%$ and $31.2 \%$ of the samples at concentrations lower than the LOQ $(25 \mu \mathrm{g} / \mathrm{kg}$ for SPX-1 and $3 \mu \mathrm{g} / \mathrm{kg}$ for PnTX-G), respectively. For the detected cyclic imines, the average exposure and the $95^{\text {th }}$ percentile were calculated. The results obtained indicate that it is unlikely that a potential health risk exists through the seafood diet for CIs in Europe. However, further information about CIs is necessary in order to perform a conclusive risk assessment.
\end{abstract}


Keywords: cyclic imines, marine toxins, shellfish, mass spectrometry, risk assessment 


\section{Introduction}

Cyclic imines (CIs) constitute a quite recently discovered group of marine biotoxins that act on neural receptors and bioaccumulate in seafood. In 2010 the European Food Safety Authority (EFSA) Panel on Contaminants in Food Chain assessed the risks to human health related to the consumption of spirolides (SPXs), gymnodimines (GYMs), pinnatoxins (PnTXs) and pteriatoxins (PtTXs) in shellfish [1].

These toxins are macrocyclic compounds with imine (carbon-nitrogen double bond) and spiro-linked ether moieties. They are grouped together due to the imino group functioning as their common pharmacore, responsible for acute neurotoxicity in mice. CIs have not been linked yet to human poisoning and are not regulated in Europe, although the EFSA requires more data to perform conclusive risk assessment for consumers [1]. Spirolides (SPXs) are the largest group of CIs in shellfish that together with gymnodimines (GYMs) are best characterized, comprising more than twenty different analogues with a similar structure. SPXs are produced by the dinoflagellate Alexandrium ostenfeldii [2, 3], GYMs are also produced by A. ostenfeldii and by Karenia selliformis [4]. The dinoflagellate Vulcanodinium rugosum produces PnTXs [5]. Pteriatoxins (PtTXs) are suggested to be bio-transformed from PnTXs in shellfish [6]. The toxicological information for CIs is limited, comprising mostly acute toxicity studies [1]. In addition, not all CIs are equally potent: SPX1 showed about 300 fold more activity than GYM-A on equimolar basis in an in vivo study about neuromuscular excitability in mice [7]. Oral toxicity of SPXs is much lower (10-100 times less toxic orally, depending on the toxin and how the toxins are administered). In contrast to spirolides, PnTXs have proven to be almost as toxic via oral dosing as they are by intraperitoneal (i.p.) injection to mice. Levels of toxicity of spirolide $\mathrm{C}$ and pinnatoxin $\mathrm{E}+\mathrm{F}$ in feed were 500 and $60\left(\mathrm{LD}_{50}\right.$, mice, $\left.\mu \mathrm{g} / \mathrm{kg}\right)$, respectively [8].

In recent years much effort has been dedicated to the development and validation of the LC-MS/MS method for multi-toxin analysis of lipophilic toxins, being the reference method in the EU since July $1^{\text {st }}, 2011$ [9]. CIs can be identified and quantified with the LC-MS/MS multitoxin method. Previously, when the MBA method was the official method for lipophilic toxins, CIs interfered with it and were responsible for false positives. As there is no Maximum Permitted Level (MPL) for CIs established in Europe, it is expected to find CIs in the market shellfish. The information about the presence of CIs in commercial samples in Europe is still limited, the magnitude of the potential arrival of CIs in the market is difficult to assess [1].

This group of emerging toxins can be addressed easily in the lipophilic method on LC-MS/MS and LC-HRMS instruments [10, 11]. Alternative analysis methods have recently been developed for CIs [12]. A fluorescent polarization assay was developed for analysis of 13-desmethyl SPX-C and GYMA in shellfish [13]. Different receptor-based methods have also been developed for CIs [14-16]. Recently the receptor-binding assay based on Torpedo-nicotinic acetylcholine receptors has been 
patented and commercialized by Abraxis using the colorimetric approach [15]. So far, LC-MS/MS has been the detection method of choice for the analysis of CIs in shellfish [17, 18].

In the EFSA report, France, Italy, the Netherlands, and Spain provided data on the occurrence of CIs in shellfish. The results for a total of 1821 samples (20 from Spain, 635 Italy, 314 the Netherlands, 852 from France) over 2002-2008 were analyzed by LC-MS/MS. In addition, PnTX G were detected in blue mussel in Norway [18] however EFSA did not include these results in the set of occurrence data of the report in 2010 [1] . Gymnodimines were not detected. 13-Desmethyl-SPX C was the SPXanalogue most often reported together with SPX A, SPX B and 13-desmethyl SPX D with a concentration range of 4-226 $\mu \mathrm{g} / \mathrm{kg}$ shellfish. In 2010, PnTX G was detected in mussel samples in the range of 5 to $30 \mu \mathrm{g} / \mathrm{kg}$, but also higher levels up to $115 \mu \mathrm{g} / \mathrm{kg}$ were found [18].

In this study, several commercial samples of bivalves (mussels, oysters, clams, scallops and cockles), raw and processed, from eight European countries were evaluated for emerging CIs. This work aimed to study the presence and concentrations of CIs found in the commercial samples, increasing the database on levels of these toxins in shellfish and consequently, to perform a risk assessment in order to determine the potential health risk for CIs through shellfish consumption.

\section{Materials and methods}

\subsection{Standards and reagents}

Certified reference material of okadaic acid (OA), dinophysistoxin-1 (DTX-1), dinophysistoxin-2 (DTX-2), yessotoxin (YTX), homoyessotoxin (hYTX), pectenotoxin-2 (PTX-2), azaspiracid-a (AZA1), azaspiracid-2 (AZA-2), azaspiracid 3 (AZA-3), gymnodimine-A (GYM-A, $5.0 \pm 0.2 \mu \mathrm{gL}^{-1}$ ), 13 desmethyl spirolide C (SPX-1, $\left.7.0 \pm 0.4 \mu \mathrm{g} \mathrm{mL}^{-1}\right)$ and pinnatoxin $\mathrm{G}\left(\operatorname{PnTX}-\mathrm{G}, 7.0 \pm 0.4 \mu \mathrm{g} \mathrm{mL}^{-1}\right)$ were purchased from the National Research Council of Canada (NRC, Halifax, NS, Canada). Pinnatoxin A was obtained from Armen Zakarian, University of California, Santa Barbara, CA, USA. Pinnatoxins E and F were obtained from Andrew I. Selwood, Cawthron Institute, Nelson, New Zealand.

HPLC methanol (MeOH) was used for extraction. For LC-MS/MS analyses, hypergrade acetronitrile (ACN) was used for separation and gradient grade. Both were purchased from Fisher Scientific, Loughborough, UK. Ultrapure water (resistivity $>18 \mathrm{M} \Omega \cdot \mathrm{cm}$ ) was obtained from a Milli-Q water purification system (Millipore Ltd., Billerica, MA, USA). Ammonium hydroxide solution eluent additive for LC-MS/MS ( $\geq 25 \%$ in $\mathrm{H}_{2} \mathrm{O}$ ) was purchased from Fluka (Steinheim, Germany).

For LC-HRMS analyses, MeCN Optima ${ }^{\circledR}$ LC/MS grade and Water Optima ${ }^{\circledR}$ LC/MS were used (both from Fisher Chemical/ Fisher Scientific, Loughborough, UK). Formic acid $\left(\mathrm{HCO}_{2} \mathrm{H}\right)$ was purchased from Sigma-Aldrich (Oslo, Norway) 


\subsection{Sampling species}

The criteria used for selecting the target species were the following: most common species consumed in the study area, potential to accumulate high concentrations of toxins, wide geographic distribution, easy identification, abundance, easy capture, large enough to provide adequate tissue for analyses, found in different habitats, from extra-EU or from EU production and from wild or farmed origin.

A total of 96 samples of seafood consumed in Europe were collected including 46 fresh samples and 50 processed samples (imported seafood, i.e. frozen or canned) from eight European countries (Italy (Goro, Caleri and La Spezia), Portugal (Lisbon), Slovenia (Maribor), Spain (Sant Carles de la Ràpita and Castelló), Norway (Oslo), Ireland (Dublin), Netherlands (Ijmuiden) and Denmark (Soeborg)).

Two sampling campaigns were carried out in 2014 and 2015. At each location, at least 3 fresh samples from local seafood and 3 processed samples were sampled at reaching a minimum of $100 \mathrm{~g}$ of edible tissue. Fresh samples were frozen at $-20^{\circ} \mathrm{C}$ and shipped to the analytical laboratory with ice by fast couriers.

The 46 fresh shellfish samples included pacific oysters (Magallana gigas), flat oyster (O. edulis), japanese clams (V. philippinarum), clams ( $R$. decussatus), surf-clams ( $S$. solida), mussels ( $M$. galloprovincialis), blue mussels (M. edulis), cockles (C. edule), scallop (A. irradians) and razor-clams (E. arcuatus). A total of 24 samples were obtained from the Mediterranean Sea and 22 samples from the north-east Atlantic Ocean.

From the 50 processed shellfish collected, 23 from South Europe (Portugal, Spain, Slovenia and Portugal) while 27 samples were from North Europe (Norway, Ireland, Denmark and the Netherlands). These samples included 13 mussels (M. galloprovincialis) of which, 5 were frozen, 1 smoked \& canned, 3 mussels were conditioned in pickle sauce, 2 mussels in brine and 2 mussels in tomato, 12 of which from the Mediterranean Sea and 1 from South America. Mussels also included 12 blue mussel (M. edulis) of which 8 were frozen, 2 in brine, and 2 canned; and 9 were from North-East Atlantic Ocean and 3 from South America, in addition to 1 green-shell mussels frozen from New Zealand. Furthermore, processed samples included 7 oysters 4 of which were frozen and 3 smoked and canned and their origin was from the Mediterranean Sea and 5 from the Pacific Ocean. Sampling also included 12 clams distributed in 10 frozen, 1 clams in brine and 1 canned baby clams which 5 are from the Mediterranean Sea, 5 from Pacific Ocean (Vietnam, Zebra, Japanese) and 1 from Pacific Ocean, 1 clams from South America. Other species such as 2 frozen Pacific scallops were from the north-east Atlantic Ocean, 1 cockle sample was canned, 1 razor clam was canned and 1 Vietnam crab was canned.

\subsection{Sample preparation}

For fresh shellfish, a triple-step extraction with methanol $(10 \mathrm{~mL})$ was performed on whole homogenate tissues (1g) according to the procedure proposed by Gerssen et al. [19] which was also 
intra-laboratory validated by our group [20] and accredited by the Spanish accreditation body following the standard ISO 17025. Crude extracts were filtered though polytetrafluoroethylene (PTFE) $0.2 \mu \mathrm{m}$ membrane syringe filters.

Processed shellfish samples were treated according to the EURLMB SOP [9]. There were four different processed shellfish: (1) packed in oil, sauce, broth and water; (2) packed in brine and other non-edible sauces; (3) cooked steamed mussels and (4) processed mussels in vacuum packed bags. It is important to take into account the known water losses during each different processing. Three different processed shellfish protocols were used.

For samples in sauce, broth and water, if the ratio solid/liquid was high (i.e >50/50) and /or heterogenic slurry was obtained, a known amount of water was added to the slurry and this was taken into account as dilution factor. After this step, the same protocol of extraction for fresh shellfish was used.

For samples packed in brine or other non-edible sauces, mussels were separated from the liquid, rinsed with water. After this mussels were drained and weighted. Then, homogenate shellfish tissue was reconstituted with 50/50 tissue/deionised water. After this step, the same protocol of extraction for fresh shellfish was used.

For samples cooked and steamed, mussels were weighted and reconstituted in 70/30 tissue/deionised water. After the homogenisation of the tissue and water, the same protocol of extraction for fresh shellfish was used.

\subsection{Instrumental analysis (LC-MS Analysis)}

Two detection methods were used for the analysis. All samples from Spain, Portugal, Slovenia and Italy were analysed by Method A. In addition, all samples from Ireland, The Netherlands, Denmark and Norway were analysed by Method B.

Method A. Samples were analyzed under alkaline elution conditions according to Garcia-Altares et al. 2013 [20]. Briefly, an Agilent 1200 LC (Agilent Inc. Palo Alto, CA) coupled to a 3200 QTRAP mass spectrometer (AB Sciex, Concord, ON, Canada) was used. Analytical separation was performed on a X-Bridge C8 column $(2.1 \times 50 \mathrm{~mm}, 3.5 \mu \mathrm{m})$ protected with a pre-column $(2.1 \times 10 \mathrm{~mm}, 3.5 \mu \mathrm{m})$ from Waters (Milford, MA, USA). A binary gradient was programmed with water (mobile phase A) and acetonitrile/water (mobile phase B) both containing $6.7 \mathrm{mM}$ of ammonium hydroxide. CIs were monitored with two Multiple Reaction Monitoring (MRM) transitions at $694.5>676.4$ and $694.5>$ 164.1 for PnTX-G, $508.4>490.4$ and $508.45>392.4$ for GYM-A, and $692.5>444.2$ and $692.5>$ 164.1 for SPX-1 in positive mode, $[\mathrm{M}+\mathrm{H}]^{+}$; two multiple reaction monitoring (MRM) transitions were monitored; identification was supported by toxin retention time and MRM ion ratios. Data was processed with Analyst 1.6.3 software and MultiQuant ${ }^{\mathrm{TM}}$ 3.0.1. software (AB Sciex, Concord, ON, 
Canada). For method A, LOD and LOQ were $5 \mu \mathrm{g} / \mathrm{kg}$ and $25 \mu \mathrm{g} / \mathrm{kg}$ for SPX-1 and GYM-A, and 0.1 $\mu \mathrm{g} / \mathrm{kg}$ and $3 \mu \mathrm{g} / \mathrm{kg}$ for PnTX-G, respectively.

Method B. A new LC-HRMS method was developed with an Orbitrap-Exactive HCD (Thermo Fisher Scientific, Bremen, Germany). Chromatography is performed on a suitable reverse phase (e.g. C-18) HPLC column, using gradient elution with $\mathrm{ACN}-\mathrm{H}_{2} \mathrm{O}$ containing $0.1 \% \mathrm{v} / \mathrm{v} \mathrm{HCO}_{2} \mathrm{H}$. The form of the gradient can be varied depending on the analytes being investigated, but is typically from $20-80 \%$ ACN over 20 minutes. The resolution was $50,000(\mathrm{~m} / \mathrm{z} 200, \mathrm{FWHM})$ at a scan rate of $2 \mathrm{~Hz}$. Parameters were optimised to: spray voltage of $3.25 \mathrm{kV}$, capillary temperature of $375{ }^{\circ} \mathrm{C}$, heater temperature of $250{ }^{\circ} \mathrm{C}$, sheath gas flow rate of 45 (arbitrary units) and auxiliary gas flow rate of 15 (arbitrary units). In positive electrospray ionisation (ESI), capillary voltage of $77.5 \mathrm{~V}$, tube lens voltage of $175 \mathrm{~V}$ and skimmer voltage of $32 \mathrm{~V}$ were used. Data was processed with Xcalibur 3.1 software (ThermoFisher Scientific, Bremen, Germany). Peaks were identified by retention time, exact mass, fragment and isotope ion, and mass accuracy ( $\pm 5 \mathrm{ppm})$ and they were quantified with the most stable fragment ion, which corresponds to the formation of the proton adduct $[\mathrm{M}+\mathrm{H}]^{+}$. Full scan data is typically acquired in positive ion mode with $70 \mathrm{~K}$ resolution over $\mathrm{m} / z 300-1000$, and MS/MS or AIF scan data with normalised collision energy (NCE) of 40 at $70 \mathrm{~K}$ resolution and $m / z$ 100-1000. For method B, LOD and LOQ were $0.1 \mu \mathrm{g} / \mathrm{kg}$ and $3 \mu \mathrm{g} / \mathrm{kg}$ for PnTX-G and PnTX-E, $0.1 \mu \mathrm{g} / \mathrm{kg}$ and $10 \mu \mathrm{g} / \mathrm{kg}$ for PnTX-F and $0.1 \mu \mathrm{g} / \mathrm{kg}$ and $30 \mu \mathrm{g} / \mathrm{kg}$ for PnTX-A, respectively.

Matrix components might influence identification parameters, such as product ion ratio, but it was not the case in our study. Product ion ratios were very reproducible in the calibration curves and the influence of the matrices fell in the tolerances ranges proposed by the Commission Decision $2002 / 657 / \mathrm{EC}$ ( $\pm 25 \%$ variation allowed) in both methods.

\subsection{Risk assessment}

\subsubsection{Exposure assessment}

To estimate human exposure to CIs, the approach from EFSA (2010a) [1] was applied, assuming a triangular distribution for shellfish consumption, characterised by three values, the minimum $(0 \mathrm{~g})$, the most probable (modal value) (100g) and the maximum (400g) [1]. In order to express human exposure per kg body weight, an average body weight (b.w) of $60 \mathrm{~kg}$ was applied. The consumption distribution was divided by this average body weight. Next, this consumption distribution (expressed in $\mathrm{kg}$ shellfish per $\mathrm{kg}$ bodyweight) was combined with concentration data of CIs in shellfish (expressed in $\mu \mathrm{g}$ per kg shellfish).

The CIs concentration data used in this exposure assessment resulted from analyses in raw and processed (frozen and imported) shellfish samples of commercial importance in Europe. Distribution 
fitting to the concentration data did not result in a good fit, hence a mean concentration value was considered (deterministic approach). Non-detects (<LOD) and non-quantified (<LOQ) were considered as zero and LOD or LOQ for LB (lower bound) and UB (upper bound) scenarios, respectively.

Combination of consumption data and concentration data to calculate the human exposure was done using the software package @RISK version 6 (Palisade Corporation, US) for Microsoft Excel. First order Monte Carlo simulations were performed considering 100,000 to estimate the CIs intake through shellfish consumption for the two scenarios (LB and UB).

\subsubsection{Risk characterisation}

To evaluate the potential health risks of the assessed human CI exposure, there are no health based guidance values available yet that can be applied [1]. Therefore, a margin of exposure (MOE) approach was used for the risk characterisation of exposure to these toxins. The MOE value was obtained by dividing the lowest lethal dose (LD50) value by the estimated 95th percentile of exposure from shellfish consumption. The LD50 values, applied in this study, amount $50 \mu \mathrm{g} / \mathrm{kg} \mathrm{b} . \mathrm{w}$. and 500 $\mu \mathrm{g} / \mathrm{kg}$ b.w. for SPXs and $150 \mu \mathrm{g} / \mathrm{kg}$ b.w. and $400 \mu \mathrm{g} / \mathrm{kg}$ b.w. for PnTXs when they were administered by gavage or in the feed, respectively $[1,6]$.

\section{Results and Discussion}

\subsection{Occurrence of CIs in marine organisms}

Taking into account the 96 raw and processed samples, CIs were detected in 52\% of them at low concentrations from 0.1 to $12 \mu \mathrm{g} / \mathrm{kg}$ for PnTX-G and 26 to $66 \mu \mathrm{g} / \mathrm{kg}$ for SPX-1. Other pinnatoxins, spirolides, gymnodimine and pteriatoxins analogues were not detected in any of the commercial shellfish samples during 2014 and 2015. Figure 1 shows the total ion chromatogram (TIC) profile of lipophilic toxin reference standard material and a processed mussel sample obtained by LC-MS/MS, as an example. Results are summarized in Table 1 and Table 2 for fresh and processed/imported samples, respectively. Both tables include information about the concentrations of the samples and their sampling location.

\section{Figure 1}

\section{Table 1}

\section{Table 2}

Results from commercial shellfish sampled in 2014, showed that only 5 samples ( 1 from Portugal, 2 from Slovenia and 2 from Spain) presented SPX-1, which 4 samples were at low concentrations (25$28 \mu \mathrm{g} / \mathrm{kg}$ ) and one sample at traces level. Moreover, PnTX-G was detected at low levels $(3-12 \mu \mathrm{g} / \mathrm{kg})$ in 6 samples (1 from Italy, 2 from Slovenia and 3 from Spain). 
Processed mussels showed higher concentrations of PnTX-G $(12 \mu \mathrm{g} / \mathrm{kg})$ than raw mussels. In addition, 6 blue mussel samples ( 1 from Ireland, 1 from Denmark, 1 from The Netherlands and 3 from Norway) showed trace levels of PnTX-G during 2014. Concentrations of PnTX-G between 0.1 to 0.4 $\mu \mathrm{g} / \mathrm{kg}$ were detected.

During the second sampling round (2015), five samples (mussels, cockles and clams from Portugal, mussels from Slovenia and Spain) contained SPX-1 at low levels $(34-65 \mu \mathrm{g} / \mathrm{kg})$, in addition traces of SPX-1 were detected in 6 more samples (mussels and oysters from Italy, mussels and clams from Portugal, and mussels and oysters from Spain). Moreover, PnTX-G was detected in three samples, 5 $\mu \mathrm{g} / \mathrm{kg}$ in mussels in tomato sauce and $3 \mu \mathrm{g} / \mathrm{kg}$ in frozen mussels from Slovenia, and $3 \mu \mathrm{g} / \mathrm{kg}$ in frozen imported mussels from Italy however traces of PnTX G were also detected in 5 other samples (mussels and clams from Portugal and Spain). In addition, in 2015 higher concentrations at 0.1$5.1 \mu \mathrm{g} / \mathrm{kg}$ levels of PnTX-G were detected from commercial samples (Ireland, Norway, the Netherlands and Denmark) in comparison with 2014 (0.1-0.4 $\mu \mathrm{g} / \mathrm{kg})$. PnTX-G was detected at trace levels of 0.1 to $0.3 \mu \mathrm{g} / \mathrm{kg}$ in clams, oysters, scallops and cockles from Ireland, Denmark, and the Netherlands. In blue mussel samples from all four countries (Ireland, Denmark, the Netherlands and Norway), PnTX-G was detected in concentrations between 0.1 to $5.1 \mu \mathrm{g} / \mathrm{kg}$, the highest concentration was found in a fresh blue mussel sample from Norway. Moreover, trace level of $0.3 \mu \mathrm{g} / \mathrm{kg}$ of PnTX-A was detected in a fresh blue mussel from Ireland. The introduction of high resolution mass spectrometry instruments may enhance the capabilities of confirmation of different CI analogues which no reference standard is commercially available.

\subsection{Differences between species and locations}

Even though mussels was the species more sampled in all locations (42 from 96 samples), CI was detected in the $69 \%$ of the mussel samples, followed by oysters (17 from 96 samples) $29 \%$ and clams (25 from 96 samples) 24\%. The frequency of detection depends on the cyclic imine group, SPX-1 was detected in higher frequency in oysters species $(23 \%)$ followed by mussels $(21 \%)$ in comparison with PnTX-G which was detected in higher frequency by mussels species $(61 \%)$ followed by clams $(23 \%)$. SPX-1 was found in $13 \%$ and $8.5 \%$ of fresh and processed sample mussels, respectively. In addition, PnTX-G was found in $11.5 \%$ and $13.5 \%$ of fresh and processed sample mussels, respectively.

Regarding concentrations in fresh samples (outliers excluded), surf-clams showed the highest mean values for SPX-1 (63 $\mu \mathrm{g} / \mathrm{kg})$ doubling the other species, except for cockles $(57 \mu \mathrm{g} / \mathrm{kg})$. Blue mussels showed the highest values for PnTX-G $(5.1 \mu \mathrm{g} / \mathrm{kg})$.

Regarding concentrations in processed samples (outliers excluded), mussels in pickle sauce showed the highest mean values for SPX-1 (66 $\mu \mathrm{g} / \mathrm{kg})$. Mussels in tomato showed the highest values for PnTX-G $(12 \mu \mathrm{g} / \mathrm{kg})$ more than doubling the other species. 
When fresh samples are grouped by location (Atlantic Ocean (Portugal), $n=5$; NE Atlantic Ocean and North Sea, $n=22$; Mediterranean Sea, $n=19$ ), the Atlantic Ocean seafood showed the highest concentrations for SPX-1 (63 $\mu \mathrm{g} / \mathrm{kg}$ in surf clams) and the North Sea showed the highest concentrations for PnTX-G (5.1 $\mu \mathrm{g} / \mathrm{kg}$ in blue mussels).

When processed/imported samples are grouped by location (South Europe, $n=23$ and North Europe, $\mathrm{n}=27$ ), the Atlantic Ocean seafood showed the highest concentration for SPX-1 (66 $\mu \mathrm{g} / \mathrm{kg}$ in mussels in pickle sauce from Portugal) and the Mediterranean Sea showed the highest concentration for PnTX-G (12 $\mu \mathrm{g} / \mathrm{kg}$ in mussels in tomato from Slovenia and imported from Spain).

The presence of SPX-1 and PnTX-G at lower and higher levels of their LOQs in the fresh and processed samples from South Europe (Spain, Portugal, Slovenia and Italy) and North Europe (Ireland, Norway, the Netherlands and Denmark) are summarized in Figure 2.

Figure 2. Presence of CIs in seafood in fresh and processed samples

Spirolides were only analyzed in South European countries $(n=47)$. Their presence was found in concentrations lower than LOQ at 7.3\% and higher than LOQ at 9.4\%. Fresh samples showed higher percentages $10.6 \%$ and $14.9 \%$ than processed samples $4.3 \%$ and $4.3 \%$ for concentrations <LOQ and $>$ LOQ, respectively.

Pinnatoxins were analysed in 96 samples from North and South European countries. Their presence was found in concentrations lower than LOQ at $31.2 \%$ and higher than LOQ at $4.2 \%$. Fresh samples showed higher percentages $16.7 \%$ and $3.13 \%$ than processed samples $14.6 \%$ and $1.04 \%$ for concentrations $<\mathrm{LOQ}$ and $>\mathrm{LOQ}$, respectively.

\subsection{Effect of processing}

The limits set by authorities for the presence of chemical contaminants and toxins in food products (Maximum permissible concentrations) and risk assessment analysis are mostly evaluated in raw products, despite most food products are cooked before consumption. The fact that food cooking, processing and eating habits are generally not considered by authorities is likely due to the diversity of cooking preparations and industrial procedures. Nevertheless neglecting their effect on seafood may lead to over- or underestimation of the risk for consumers and to misleading dietary advice [21]. Information on the effects of processing on emerging toxins is scarce.. In this study, fresh samples from different species and processed samples from different species obtained by different manufacturing processes such as canned shellfish in sauce (pickle or tomato sauce), in brine, cooked steamed shellfish and processed shellfish in vacuum packed bags were evaluated. 
Cyclic imines were present in higher frequency in fresh samples (46 fresh from 96 samples) 65\% in comparison with processed samples $40 \%$, where PnTX-G showed the highest presence in both, fresh and processed samples, 39\% and 32\%, respectively. Processed mussels showed higher concentrations of PnTX-G $(12 \mu \mathrm{g} / \mathrm{kg})$ than fresh mussels. Effects of the industrial steaming and of the industrial canning on the toxicity of mussels contaminated with DSP toxins have been already evaluated by Blanco et al [22, 23].

Regarding the different species analyzed, processed mussels present a higher frequency of detection in mussels $(30 \%)$ followed by clams $(2 \%)$. This trend was similarly observed in fresh samples for PnTX-G (24\% mussels and 6\% clams). For spirolides (SPX-1), a higher frequency in mussels was also observed in both processed (6\%) and fresh samples (13\%) followed by oysters (2\% and 6\%, respectively). It is known that cooking or, in general, thermal processing of molluscs produces dehydration of the meat and consequently a weight decrease, while the degradation of lipophilic toxins is zero or very limited $[23,24]$. In this sense, an increase in the concentration of lipophilic toxins due to industrial steaming should be expected. However, the increments observed by the food processing industries were too high as to be explained only by dehydration [24].

Regarding the effect of industrial steaming, it can be expected that mussels with toxicities below the regulatory limit could easily surpass that level after industrial steaming, thus producing important losses for food processor [24]. In addition, the effect of canning in pickled sauce and autoclaving was also evaluated by Blanco et al. for DSP toxins. Autoclaving produced a reduction of the weight of the canned mussels. The weight loss is important (average 25.5\%) but smaller than the one that took place by steaming (around 30\%). During the sterilization process, the toxin content of the mussels was reduced. Only a small part of this reduction is due to the transfer of the toxins in the sauce. Therefore, the analysis of the whole can content or the mussel meat once rehydrated seems to be the most equivalent to the raw mussel controls. In this study EURLMB SOP annex regarding processed shellfish samples was followed [9] in order to compare the raw and the processed samples in the most similar conditions as possible. Even though, CIs are lipophilic toxins and the highest concentrations found for SPX-1 $(12 \mu \mathrm{g} / \mathrm{kg})$ and PnTX-G $(66 \mu \mathrm{g} / \mathrm{kg})$ were in mussels in sauce (pickle sauce and in tomato).

\subsection{Spirolides and pinnatoxins exposure}

The concentration data from raw, frozen and imported samples reported in Table 1 and 2 were used to perform the exposure assessment for spirolides (SPX1) and pinnatoxins (PnTX-G) (with exclusion of the concentration data for "mussels in pickle sauce"). Several species were considered, namely mussels, oysters, cockles and clams from different geographical origins. For spirolides, the mean value of the concentration data for the lower-bound (LB) scenario is equal to $21 \mu \mathrm{g} / \mathrm{kg}$ shellfish meat, and the mean value for the upper-bound (UB) scenario amounts $32 \mu \mathrm{g} / \mathrm{kg}$ shellfish meat. Based on these mean concentration values and based on a triangular distribution for consumption as described 
above, the spirolides distribution of exposure for the LB scenario is described by a mean value of 0.06 $\mu \mathrm{g} / \mathrm{kg}$ bw and a $95^{\text {th }}$ percentile of $0.11 \mu \mathrm{g} / \mathrm{kg}$ bw. The distribution of exposure for the UB scenario is described by a mean value of $0.09 \mu \mathrm{g} / \mathrm{kg}$ bw and a $95^{\text {th }}$ percentile of $0.17 \mu \mathrm{g} / \mathrm{kg}$ bw.

Regarding pinnatoxins, the mean value of the concentration data for the LB scenario is equal to 1.09 $\mu \mathrm{g} / \mathrm{kg}$ shellfish meat, and the mean value for the UB scenario amounts $1.33 \mu \mathrm{g} / \mathrm{kg}$ shellfish meat. Based on these pinnatoxin mean concentration values and based on a triangular distribution for consumption as described above, the distribution of exposure for the LB scenario is described by a mean value of $0.003 \mu \mathrm{g} / \mathrm{kg}$ bw and a $95^{\text {th }}$ percentile of $0.006 \mu \mathrm{g} / \mathrm{kg}$ bw. The distribution of exposure for the UB scenario is described by a mean value of $0.004 \mu \mathrm{g} / \mathrm{kg}$ bw and a $95^{\text {th }}$ percentile of 0.007 $\mu \mathrm{g} / \mathrm{kg}$ bw.

\subsection{Risk characterisation}

Risk managers should be informed about the magnitude of a MOE that could be considered to represent a low priority for risk management actions. In general it can be stated that the higher the MOE, the lower the degree of concern. Here we consider the MOE described by the EFSA representing a low priority for risk management for the different CIs toxins [1]. In EFSA report, it was concluded that a MOE range, based on the estimated exposure to SPXs, of 1000-10000 does not raise concern for the health of the consumer.

When performing a MOE approach on the data of SPXs available from Table 1 and 2, and when considering the lowest LD50 value of $50 \mu \mathrm{g} / \mathrm{kg}$ b.w. and the estimated $95^{\text {th }}$ percentile of exposure $(0.11-0.17 \mu \mathrm{g} / \mathrm{kg} \mathrm{bw})$, the calculated MOE values amount were $294-455$. When considering the highest LD50 value of $500 \mu \mathrm{g} / \mathrm{kg}$ bw, the calculate MOE values amount were $2941-4545$. Hence, the resulted MOE values in this study are within a smaller range than the range of 1000-10000 mentioned in the EFSA report.

Due to the fact that toxicity data is very limited, it is difficult to determine a "threshold MOE" value for which no health concern can be concluded. But it is of importance that with the available recent data, the MOE values are substantially lower than reported by EFSA. However, it is stated that the LD50 following administration of SPXs in the feed $(500 \mu \mathrm{g} / \mathrm{kg} \mathrm{bw})$ is more likely to be of relevance for the risk assessment through consumption of shellfish contaminated with SPXs. Based on this assumption, and hence based on the MOE range of 2941 - 4545, it may be concluded that it is unlikely that a health risk exists due to the exposure to SPXs through shellfish consumption.

EFSA was not able to estimate the exposure to PnTXs based on the occurrence data officially submitted to EFSA (2010a). As data on PnTXs was collected within the present study, an attempt is made to assess the health risk due to PnTX G exposure via seafood consumption. A similar approach as for SPXs is used. The oral LD50 values for PnTX G in mice were in the region of $150 \mu \mathrm{g} / \mathrm{kg}$ bw 
and $400 \mu \mathrm{g} / \mathrm{kg}$ bw when PnTX G was administered by gavage in fed mice or in the feed, respectively [6].

When considering the lowest LD50 value of $150 \mu \mathrm{g} / \mathrm{kg}$ bw and the estimated $95^{\text {th }}$ percentile of exposure $(0.006-0.007 \mu \mathrm{g} / \mathrm{kg} \mathrm{bw})$, the calculated MOE values amount were $21429-25000$. Hence, the resulted MOE values, based on the lowest LD50 value, in this study are substantially higher than the range of 1000-10000 mentioned in the EFSA report. Therefore based on the available data and based on this approach, it may be concluded that it is unlikely that a health risk exists due to the exposure to PnTX G through shellfish consumption.

\section{Conclusions}

The presence of CIs was evaluated in 96 samples from eight European countries (Spain, Portugal, Italy, Slovenia, Ireland, The Netherlands, Denmark and Norway). SPX-1 and PnTX-G were detected in $7.3 \%$ and $31.2 \%$ at lower concentrations than LOQ (25 $\mu \mathrm{g} / \mathrm{kg}$ for SPX-1 and $3 \mu \mathrm{g} / \mathrm{kg}$ for PnTX-G) and, $9.4 \%$ and $4.2 \%$ at higher concentrations than LOQ, respectively.

A risk assessment study was performed based on the methodology described by EFSA. It may be concluded that it is unlikely that a health risk exists due to the exposure to SPXs and PnTXs through shellfish consumption. These results and conclusions are based on the available data. However, more data on toxicity and processed samples would be necessary to complete the risk assessment study for CIs requested by EFSA. Thus, CIs should be included in the shellfish safety monitoring programmes of lipophilic marine toxins by LC-MS methods, even if they are not regulated, to better assess their presence in shellfish and favour exposure studies that would enable a reliable risk analysis for consumers.

\section{Acknowledgements}

The research leading to these results has received funding from the European Union's Seventh Framework Programme (FP7/2007-2013) under grant agreement no 311820 (ECsafeSEAFOOD). We acknowledge also the Instituto Nacional de Investigación y Tecnología Agraria y Alimentaria (INIA) providing funding from the project PROMAQUA (RTA2013-00096-00-00) and CERCA Programme/Generalitat de Catalunya. 


\section{References}

[1] European Food Safety Authority (EFSA), Panel on Contaminants in the Food Chain (CONTAM). Scientific Opinion on marine biotoxins in shellfish-Cyclic imines (spirolides, gymnodimines, pinnatoxins and pteriatoxins). EFSA J. 2010, 8: 1628-1667.

[2] Cembella, A. D., Lewis, N. I., \& Quilliam, M. A. The marine dinoflagellate Alexandrium ostenfeldii (Dinophyceae) as the causative organism of spirolide shellfish toxins. Phycologia 39(1) (2000) 67-74.

[3] Touzet, N., Franco, J. M., \& Raine, R. Morphogenetic diversity and biotoxin composition of Alexandrium (Dinophyceae) in Irish coastal waters. Harmful Algae 7(6) (2008) 782-797.

[4] Kremp, A., Tahvanainen, P., Litaker, W., Krock, B., Suikkanen, S., Leaw, C. P., \& Tomas, C. Phylogenetic relationships, morphological variation, and toxin patterns in the Alexandrium ostenfeldii (Dinophyceae) complex: Implications for species boundaries and identitites. Journal of Phycology, 50(1) (2014) 81-100.

[5] Rhodes, L., Smith, K., Selwood, A., McNabb, P., Munday, R., Suda, S., Molenaar, S., \& Hallegraeff, G. Dinoflagellate Vulcanodinium rugosum identified as the causative organism of pinnatoxins in Australia, New Zealand and Japan. Phycologia 50(6) (2011) 624-628.

[6] Munday R. Toxicology of cyclic imines: gymnodimine, spirolides, pinnatoxins, pteriatoxins, prorocentrolide, spiro-prorocentrimine, and symbioimines. In: Seafood and Freshwater toxins: Pharmacology, Physiology and Detection. 2nd edition. Ed LM Botana. CRC Press (Taylor and Francys Group), Boca Raton, FL, 2008, 581-594.

[7] Marrouchi R, Rome G, Kharrat R, Molgò J, Analysis of the action of gymnodimine-A and 13desmethyl spirolide $\mathrm{C}$ on the mouse neuromuscular system in vivo. Toxicon 2013, 75: 27-34.

[8] Miles CO, Rundberget T, Sandvik M, Aasen JAB, Selwood A.I, NVI Report series (Report 07b) 2010 (ISSN 1890-3290).

[9] EU-Harmonised Standard Operating Procedure for determination of Lipophilic marine biotoxins in molluscs by LC-MS/MS. EURLMB, version 5, 2015.

[10] M. García-Altares, A. Casanova, V. Bane, J. Diogène, A. Furey, P. de la Iglesia. Confirmation of pinnatoxins and spirolides in shellfish and passive samplers from Catalonia (Spain) by liquid chromatography coupled with triple quadrupole and high-resolution hybrid tandem mass spectrometry. Mar. Drugs 12 (2014) 3706-3732.

[11] K. Davidson, C. Baker, C. Higgins, W. Higman, S. Swan, A. Veszelovszki, A.D. Turner. Potential threats posed by new or emerging marine biotoxins in UK waters and examination of detection used for their control: cyclic imines. Mar. drugs 13 (2015) 7087-7112.

[12] A. Abraham, M. Rambla-Alegre. Marine toxins analysis for consumer protection. In: Comprehensive Analytical Chemistry. Recent advances in the analysis of marine toxins. 1st edition. Ed. J. Diogène, M. Campàs. Elsevier (Wilson \& wilson's), Netherlands, 2017, 343-378. 
[13] N. Vilariño, E.S. Fonfria, J. Molgó, R. Aráoz, L.M. Botana. Detection of gymnoimine-A and 13desmethyl C spirolide phycotoxins by fluorescence polarization. Anal. Chem. 81 (2009) 2708-2714.

[14] L.P. Rodriguez, N. Vilariño, J. Molgó, R. Aráoz, A. Antelo, M.R. Vieytes, L.M. Botana. Solidphase receptor-based assay for the detection of cyclic imines by chemiluminescence, fluorescence or colorimetry. Anal. Chem. 83 (2011) 5857-5863.

[15] R. Aráoz, S. Ramos, F. Pelissier, V. Guérineau, E. Benoit, N. Vilariño, L.M. Botana, A. Zakarian, J. Molgó. Coupling the Torpedo Microplate-receptor binding assay with mass spectrometry to detect cyclic imine neurotoxins. Anal. Chem. 84 (2012) 10445-10453.

[16] L.P. Rodríquez, N. Vilariño, J. Molgó, R. Aráoz, M.C. Louzao, P. Taylor, T. Talley, L.M. Botana. Development of a solid-phase receptor-based assay for the detection of cyclic imines using a microsphere-flow cytometry system. Anal. Chem. 85(4) (2013) 2340-2347.

[17] Hess P., Abadie E., Hervé F., Berteaux T., Séchet V., Aráoz R., Molgó J., Zakarian A., Sibat M., Rundberget T., Miles C.O., Amzil Z. Pinnatoxin G is responsible for atypical toxicity in mussels (Mytilus galloprovincialis) and clams (Venerupis decussata) from Ingril, a French Mediterranean lagoon. Toxicon 75 (2013) 16-26.

[18] Rundberget T., Bunaes Aasen J.A., Selwood A.I., Miles C.O. Pinnatoxins and spirolides in Norwegian blue mussels and seawater. Toxicon 58 (2011) 700-711.

[19] Gerssen, A.; Mulder, P.; McElhinney, M.A.; de Boer, J. Liquid chromatography-tandem mass spectrometry method for the detection of marine lipophilic toxins under alkaline conditions. J. Chromatogr. A 2009, 1216, 1421-1430.

[20] García-Altares, M.; Diogène, J.; de la Iglesia, P. The implementation of liquid chromatography tandem mass spectrometry for the official control of lipophilic toxins in seafood: Single-laboratory validation under four chromatographic conditions. J. Chromatogr. A 2013, 1275, 48-60.

[21] Kroes, R., D. Muller, J. Lambe, M. R. H. Lowik, J. van Klaveren, J. Kleiner, R. Massey, S. Mayer, I. Urieta, P. Verger and A. Visconti (2002). "Assessment of intake from the diet." Food and Chemical Toxicology 40(2-3): 327-385.

[22] Blanco J, Arévalo F, Correa J, Corina Porro M, Cabado AG, Vieites JM, Moroño A. Effect of the Industrial steaming on the toxicity, estimated by LC-MS. Effect of the Industrial Steaming on the Toxicity, Estimated by LC-MS/MS, of Mussels Exposed for a Long Time to Diarrhetic Shellfish Poisoning (DSP) Toxins. Food chemistry 2015, 177: 240-247.

[23] Blanco J., Arévalo F, Correa J., Corina Porro M., Cabado A.G., Vieites J.M., Moroño A. Effect of the industrial canning on the toxicity of mussels contaminated with diarrhetic shellfish poisoning (DSP) toxins. Toxicon 112 (2016) 1-7.

[24] Marques A., Lourenço H.M., Nunes M.L., Roseiro C., Santos Ca., Barranco A., Rainieri S., Langerholc T., Cencic A. New tools to assess toxicity, bioaccessibility and uptake of chemical contaminants in meat and seafood. Food Research International 44 (2011) 510-522. 

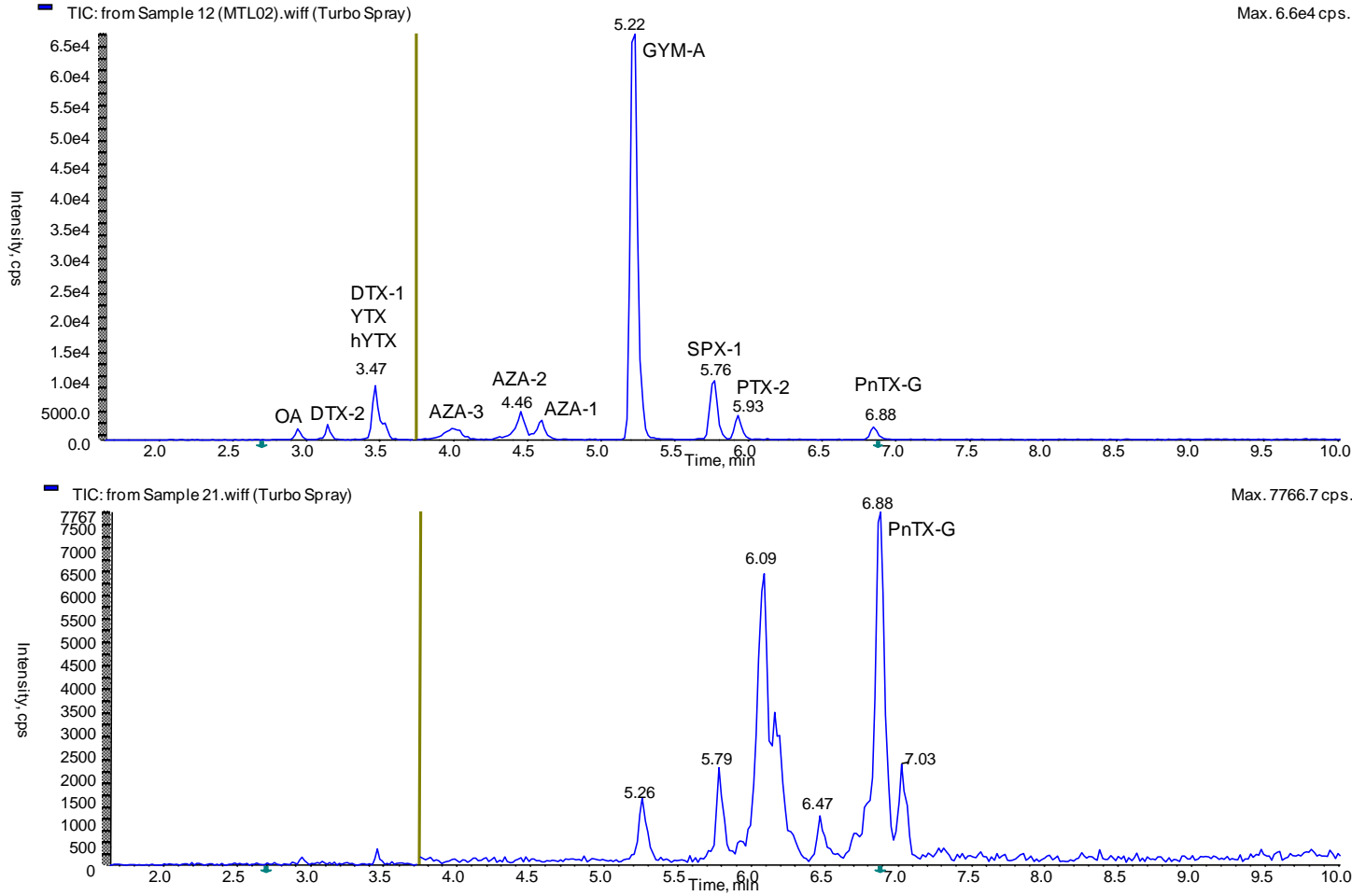

Figure 1. Total Ion Chromatogram of transition monitored obtained following the analysis of lipophilic toxins including cyclic imines by LC-MS/MS. a) lipophilic standards (including OA, DTX-1,DTX-2, YTX, hYTX, AZA-1, AZA-2, AZA-3, GYM-A, SPX-1, PTX-2 and PnTX-G) and $\mathrm{b}$ ) mussel processed sample. 


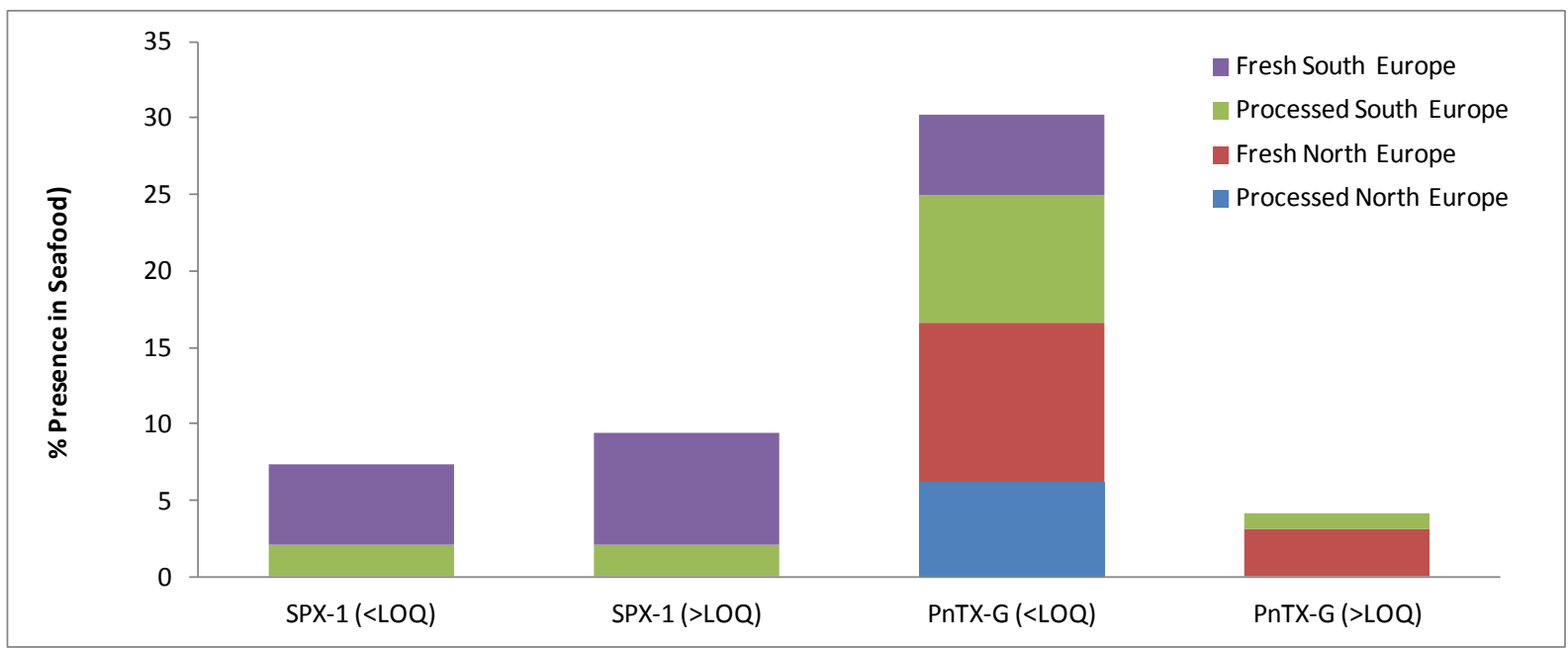

Figure 2. Presence of CIs in seafood in fresh and processed samples 
Table 1

Cyclic imine concentrations in raw samples $(\mu \mathrm{g} / \mathrm{kg})$

\begin{tabular}{|c|c|c|c|c|}
\hline $2014(n=21)$ & & & & \\
\hline Species & $\begin{array}{l}\text { SPX-1 } \\
(\mathrm{n}: 47)\end{array}$ & $\begin{array}{l}\text { PnTX-G } \\
(n: 96)\end{array}$ & $\begin{array}{l}\text { PnTX-A } \\
(\mathbf{n}: 96)\end{array}$ & $\begin{array}{c}\text { Origin } \\
\left(\mathrm{n}^{\mathrm{o}} \text { samples }\right)\end{array}$ \\
\hline $\begin{array}{l}\text { Mussel }(\mathrm{n}=3) \\
\text { (M. galloprovincialis })\end{array}$ & nd, 26, 28 & nd, nd, 4 & nd & Italy (1), Slovenia (1) and Spain \\
\hline $\begin{array}{l}\text { Blue mussels }(\mathrm{n}=5) \\
\text { (M. edulis) }\end{array}$ & nd & $\begin{array}{l}\text { nq, nd, } \\
\text { nq, nq, nq }\end{array}$ & nd & $\begin{array}{c}\text { Ireland (1), Denmark (2) and } \\
\text { Norway (2) }\end{array}$ \\
\hline $\begin{array}{l}\text { Flat oyster }(\mathrm{n}=5) \\
(\text { O. edulis })\end{array}$ & $\begin{array}{l}\text { nd, nd, } \\
27, \text { nq, nd }\end{array}$ & $\begin{array}{c}\text { nd, nd, } 4, \\
\text { nd, nd }\end{array}$ & nd & $\begin{array}{l}\text { Portugal (1), Italy (1), Slovenia } \\
\text { (1) Spain (1), and Denmark (1) }\end{array}$ \\
\hline $\begin{array}{l}\text { Pacific oyster }(\mathrm{n}=1) \\
\text { (C. gigas) }\end{array}$ & nd & nd & nd & Ireland (1) \\
\hline $\begin{array}{l}\text { Clams }(\mathrm{n}=1) \\
(\text { R. decussatus })\end{array}$ & nd & 4 & nd & Italy (1) \\
\hline $\begin{array}{l}\text { Japanese Clams }(\mathrm{n}=3) \\
(\text { V. philippinarum })\end{array}$ & nd & nd & nd & $\begin{array}{c}\text { Portugal (1), Spain (1) and } \\
\text { Slovenia (1) }\end{array}$ \\
\hline $\begin{array}{l}\text { Surf-clams }(\mathrm{n}=1) \\
(\text { S. solida })\end{array}$ & nd & nd & nd & Denmark (1) \\
\hline $\begin{array}{l}\text { Cockles }(\mathrm{n}=2) \\
(\text { C. edule })\end{array}$ & nd & nd & nd & Ireland (1) and Norway (1) \\
\hline $2015(n=25)$ & & & & \\
\hline $\begin{array}{l}\text { Mussel }(\mathrm{n}=4) \\
\text { (M. galloprovincialis) }\end{array}$ & $\begin{array}{l}\text { nq, nq, } \\
34,33\end{array}$ & $\begin{array}{l}\text { nd, nd, } \\
\text { nq, nd }\end{array}$ & nd & $\begin{array}{c}\text { Italy (1), Portugal (1), Spain (1), } \\
\text { and Slovenia (1) }\end{array}$ \\
\hline $\begin{array}{l}\text { Blue mussels }(\mathrm{n}=5) \\
(M . \text { edulis })\end{array}$ & nd & $\begin{array}{c}4.6, \mathrm{nq} \\
\mathrm{nq}, 5.1 \\
3.5\end{array}$ & $\begin{array}{l}\text { nq, nd, } \\
\text { nd, nd, nd }\end{array}$ & $\begin{array}{l}\text { Ireland (1), Denmark (1), The } \\
\text { Netherland (1) and Norway (2) }\end{array}$ \\
\hline $\begin{array}{l}\text { Flat oyster }(\mathrm{n}=1) \\
(\text { O. edulis })\end{array}$ & nd & nd & nd & Italy (1) \\
\hline $\begin{array}{l}\text { Pacific oyster }(\mathrm{n}=3) \\
(\text { C. } \text { gigas })\end{array}$ & $\mathrm{nq}, \mathrm{nd}, \mathrm{nd}$ & $\mathrm{nd}, \mathrm{nd}, \mathrm{nq}$ & nd & $\begin{array}{c}\text { Spain (1), Ireland (1) and } \\
\text { Denmark (1) }\end{array}$ \\
\hline $\begin{array}{l}\text { Clams }(\mathrm{n}=3) \\
\text { (R. decussatus) }\end{array}$ & nd, nq, nd & nd, nq, nd & nd & $\begin{array}{c}\text { Italy (1), Portugal (1) and The } \\
\text { Netherlands (1) }\end{array}$ \\
\hline $\begin{array}{l}\text { Japanese Clams }(\mathrm{n}=2) \\
(\text { V. philippinarum })\end{array}$ & nd & nd & nd & Spain (1) and Slovenia (1) \\
\hline $\begin{array}{l}\text { Surf-clams }(\mathrm{n}=2) \\
(\text { S. solida })\end{array}$ & 63, nd & $\mathrm{nd}, \mathrm{nq}$ & nd & Portugal (1) and Ireland (1) \\
\hline $\begin{array}{l}\text { Cockles }(\mathrm{n}=2) \\
(\text { C. edule })\end{array}$ & 57 , nd & $\mathrm{nd}, \mathrm{nq}$ & nd & $\begin{array}{l}\text { Portugal (1) and The Netherlands } \\
\text { (1) }\end{array}$ \\
\hline $\begin{array}{l}\text { Scallop }(\mathrm{n}=2) \\
\text { (A. irradians) }\end{array}$ & nd & $\mathrm{nd}, \mathrm{nq}$ & nd & Slovenia (1) and Denmark (1) \\
\hline $\begin{array}{l}\text { Razor clam }(\mathrm{n}=1) \\
\text { (E. arcuatus })\end{array}$ & nd & nd & nd & The Netherlands (1) \\
\hline
\end{tabular}


Table 2

Cyclic imine concentrations in processed samples $(\mu \mathrm{g} / \mathrm{kg})$

\begin{tabular}{|c|c|c|c|}
\hline \multicolumn{4}{|l|}{$2014(n=26)$} \\
\hline Species & $\begin{array}{l}\text { SPX-1 } \\
(n: 47)\end{array}$ & $\begin{array}{l}\text { PnTX-G } \\
(\mathbf{n}: 96)\end{array}$ & $\begin{array}{c}\text { Origin } \\
\left(\mathrm{n}^{0} \text { samples }\right)\end{array}$ \\
\hline $\begin{array}{l}\text { Mussel frozen/canned }(\mathrm{n}=3) \\
\text { (M. galloprovincialis) }\end{array}$ & nd & 4,4, nd & Italy (1), Spain (1) and Ireland (1) \\
\hline $\begin{array}{l}\text { Mussel in tomato }(\mathrm{n}=1) \\
\text { (M. galloprovincialis) }\end{array}$ & nd & 12 & Slovenia (1) \\
\hline $\begin{array}{l}\text { Mussel in brine }(\mathrm{n}=1) \\
\text { (M. galloprovincialis) }\end{array}$ & nd & 6 & Spain (1) \\
\hline $\begin{array}{l}\text { Mussel in pickle sauce }(\mathrm{n}=1) \\
\text { (M. galloprovincialis) }\end{array}$ & 26 & nd & Portugal (1) \\
\hline $\begin{array}{l}\text { Blue mussels } \\
\text { frozen/smoked\&canned } \\
(\mathrm{n}=7)(\text { M. edulis })\end{array}$ & nd & $\begin{array}{l}\text { nd, nq, } \\
\text { nd, nd, } \\
\text { nd, nd, nq }\end{array}$ & $\begin{array}{c}\text { Denmark (1), Netherlands (5) and } \\
\text { Norway (1) }\end{array}$ \\
\hline $\begin{array}{l}\text { Oyster frozen/smoked\&canned } \\
(\mathrm{n}=3)(\text { C. gigas })\end{array}$ & nd & nd & $\begin{array}{c}\text { Italy (1), Denmark (1) and Ireland } \\
\text { (1) }\end{array}$ \\
\hline $\begin{array}{l}\text { Clams frozen/canned }(\mathrm{n}=5) \\
(\text { R. decussatus })\end{array}$ & nd & nd & $\begin{array}{c}\text { Portugal (2), Italy (1), Spain (1) } \\
\text { and Denmark (1) }\end{array}$ \\
\hline $\begin{array}{l}\text { Surf-clams }(\mathrm{n}=1) \\
(\text { S. solida })\end{array}$ & nd & nd & Slovenia (1) \\
\hline $\begin{array}{l}\text { Scallops }(\mathrm{n}=2) \\
(\text { A. irradians })\end{array}$ & nd & nd & Norway (1) and Denmark (1) \\
\hline $\begin{array}{l}\text { Cockles canned }(\mathrm{n}=1) \\
(C . \text { edule })\end{array}$ & nd & nd & The Netherlands (1) \\
\hline $\begin{array}{l}\text { Razor clam }(\mathrm{n}=1) \\
(\text { E. arcuatus })\end{array}$ & nd & nd & The Netherlands (1) \\
\hline \multicolumn{4}{|l|}{$2015(n=24)$} \\
\hline $\begin{array}{l}\text { Mussel frozen/canned }(\mathrm{n}=3) \\
\text { (M. galloprovincialis) }\end{array}$ & nd & $3, \mathrm{nd}, 3$ & $\begin{array}{c}\text { Italy (1), Portugal (1), Slovenia } \\
\text { (1) }\end{array}$ \\
\hline $\begin{array}{l}\text { Mussel in tomato }(\mathrm{n}=1) \\
(\text { M. galloprovincialis) }\end{array}$ & nd & 5 & Slovenia (1) \\
\hline $\begin{array}{l}\text { Mussel in pickle sauce }(\mathrm{n}=2) \\
\text { (M. galloprovincialis) }\end{array}$ & $66, \mathrm{nq}$ & nq, nq & Portugal (1) and Spain (1) \\
\hline $\begin{array}{l}\text { Blue mussels frozen/canned/in } \\
\text { brine }(\mathrm{n}=5)(\text { M. edulis })\end{array}$ & nd & $\begin{array}{l}\text { nd, nq, nq, } \\
\text { nq, nq }\end{array}$ & $\begin{array}{l}\text { The Netherlands (1) and Norway } \\
\text { (4) }\end{array}$ \\
\hline $\begin{array}{l}\text { Green mussels frozen }(\mathrm{n}=1) \\
(\text { Perna canaliculus })\end{array}$ & nd & nq & The Netherlands (1) \\
\hline $\begin{array}{l}\text { Oyster frozen/smoked\&canned } \\
(\mathrm{n}=4)(\text { C. gigas })\end{array}$ & $\mathrm{nq}$ & nd & $\begin{array}{c}\text { Italy (1), Ireland (1), Denmark } \\
(2),\end{array}$ \\
\hline $\begin{array}{l}\text { Clams frozen }(\mathrm{n}=6) \\
(\text { R. decussatus })\end{array}$ & nd & $\begin{array}{l}\text { nd, nq, nd, } \\
\text { nd, nd, nd }\end{array}$ & $\begin{array}{l}\text { Italy (1), Portugal (1), Spain (1), } \\
\text { Slovenia (1), Ireland (1) and The } \\
\text { Netherlands (1) }\end{array}$ \\
\hline $\begin{array}{l}\text { Clams in brine }(\mathrm{n}=1) \\
\text { (V. philippinarum })\end{array}$ & nd & nd & Spain (1) \\
\hline Crab shredded \& canned $(\mathrm{n}=1)$ & nd & nd & Ireland (1) \\
\hline
\end{tabular}

